\title{
Sistem Pengujian Tegangan Boost Converter Pada Pembangkit ListrikTenaga Air (PLTH) Picohydro Kapasitas Rendah
}

\author{
M. Suyanto ${ }^{1}$, Subandi ${ }^{2}$, Syafriyudin ${ }^{3}$, Isa Mubarok ${ }^{4}$ \\ 1,2,3,4 Jurusan Teknik Elektro, Institut Sains \& Teknologi AKPRIND Yogyakarta \\ J1.Kalisahak No 28 Komplek Balapan Jogjakarta (0274) 563029, Fax. (0274)563847 \\ e-mail: myanto@akprind.ac.id ${ }^{1}$, dien@akprind.ac.id ${ }^{2}$, isamubarok70@gmail.com ${ }^{4}$
}

\begin{abstract}
Abstrak. Pengujian tegangan, pada pembangkit listrik tenaga hybrid (PLTH), menggunakan dua sumber yaitu pembangkit tenaga surya/matahari dan pembangkit tenaga kincir air. Komponen penunjang untuk menghasilkan konversi energi listrik salah satunya adalah boostconverter yang menjadi pokok bahasan utama.Oleh karena itu penulis tertarik untuk membuat dan menguji tegangan,pada boost converter dengan tujuan untuk memaksimalkan kinerja dari genertator DC sebagai pensupplay batterai/accu pada PLTH pico hydro.Sumber tegangan dc dari konverter DC-DC dapat diperoleh dari generator, atau sumber tegangan ac yang disearahkan AC to DC. Sedangkan Dc-dc converter merupakan rangkaian elektronika daya, untuk mengubah suatu masukan tegangan dc to dc menjadi tegangan keluaran dengan nilai lebih besar. Hasil pengujian tegangan dari data dilapangan dapat disimpulkan sebagai berikut.Hasil pengujian tegangan boost converter, pada Pembangkit Listrik Tenaga Hybrid Pico Hydro dapat menghasilkan tegangan sebesar 13 volt dari output Generator DC sebesr 8,39 volt. Tegangan keluaran yang dihasilkan oleh boost converter sebesar 13,4 volt, dapat stabil walaupun tegangan keluaran dari generator berubah-ubah.Dengan penambahan alat boost converter pada PLTH pico hydro, dapat membantu pengisian baterai/accu untuk mengisi tegangan yang dibutuhkan baterai yaitu 12 volt, dari boos convevter 13,4 volt lama waktu pengisian accu 5,3 jam.
\end{abstract}

Kata kunci: Boost konventer, Generator DC, PLTMh, Accu

\begin{abstract}
Voltage testing, on hybrid power plants (PLTH), uses two sources that are solar/solar power plants and waterwheel power plants. Supporting components to produce electric energy conversion one of them is boostconverter which is the main subject. Therefore the author is interested in making and testing the voltage, on the boost converter with the aim to maximize the performance of the DC Genertator as a pensupplay Batterai/accu on PLTH Pico Hydro. The DC-voltage source of the DC-DC converter can be obtained from a generator, or an AC voltage source that is air-conditioned to DC. While Dc-DC converter is a power electronic circuit, to convert a DC to DC voltage input into the output voltage with a greater value. The test results of the voltage from the field data can be concluded as follows. The voltage boost converter test results, on the Pico Hydro Hybrid power plant can produce a voltage of 13 volts from the output DC Generator 8.39 Volt. The output voltage generated by the boost converter is 13.4 volts, can be stable although the output voltage of the generator is variable. With the addition of the tool boost converter on PLTH Pico Hydro, can help battery charging/ACCU to charge the required voltage of the battery is 12 volts, from the boos convevter 13.4 volt long time charging ACCU 5.3 hours.
\end{abstract}

Keywords: Boost konventer, DC Generator, PLTMh, ACCU

\section{PENDAHULUAN}

Potensi sumber energi terbarukan di Indonesia meliputi $4,8 \mathrm{KWh} / \mathrm{m}^{2} /$ hari energi surya, $458 \mathrm{GW}$ biomassa, 3-6 m/s tenaga angin, dan $3 \mathrm{GW}$ nuklir (cadangan uranium). Selain itu Indonesia juga memiliki sumber energi hidro yang besar dengan total potensial diperkirakan $75.67 \mathrm{GW}$. Akan tetapi potensi besarnya tidak diimbangi dari energi terbarukan seperti biomassa, panas bumi, energi surya, energi air, energi angin, dan energi lautan relative tinggi, namun tidak digunakan secara signifikan.

Sistem energi hibrida adalah salah satu energi terbarukan yang menjadi popular sebagai sistem tenaga listrik yang dapat berdiri sendiri untuk menyediakan listrik. Sistem tenaga hibrida, secara umumnya terdiri dari dua atau lebih sumber energi terbarukan yang digunakan bersama untuk menyediakan peningkatan efisiensi sistem serta keseimbangan yang lebih besar dalam pasokan energi. Dalampengujian tegangansystem pembangkit listrik tenaga hybrid (PLTH), menggunakan dua sumber tenaga pembangkit yaitu pembangkit tenaga surya/matahari dan pembangkit dari tenaga kincir air. Pada pembangkit tenaga surya/matahari dan pembangkit tenaga kincir air terdapat beberapa komponen penunjang untuk menghasilkan konversi energi listrik yang layak untuk digunakan salah satu nya adalah boostconverter yang menjadi pokok bahasan utamadimana fungsinya adalah untuk mengubah suatu masukan tegangan DC menjadi tegangan DC keluaran dengan nilai yang lebih besar tegangan masukan.

Penggunaan jumping water pada pltmh irigasi dengan menggunakan kincir air jenis breastshot dapat meningkatkan putaran kincir seiring dengan meningkat nya sudut jumping water [14]

Oleh karena itu penulis tertarik untuk membuat dan mengujitegangan suatu alat boost converter pada penerapan Pembangkit Listrik Tenaga Hybrid (PLTH) pico hydrodengan tujuan untuk memaksimalkan kinerja 
dari genertator DC menuju batterai/accu pada PLTH pico hydro.

\section{METODE}

Metode yang digunakan dalam penelitian, terdiri dari, melakukan studi kepustakaan sebagai referensi yang berkaitan dengan penelitian yang dilakukan.Mengkaji relevan yang bersesuaian dengan perancangan boost converter pada PLTH pico hydro.Perancangan boost converter pada PLTH pico hydrodengan membuat sistem blok diagram. Melakukan pengujian dengan mensimulasi perancangan boost converter sebagai penaik tegangan pada PLTH pico hydro.Dalam perancangan tahap pertama adalah membuat diagram blok rangkaian, kemudianmemilih rangkaian komponen yang akan digunakan dan disimulasikan sesuai dengan kebutuhan. Blok diagram Gambar 1. Flowchart perancangan alat.

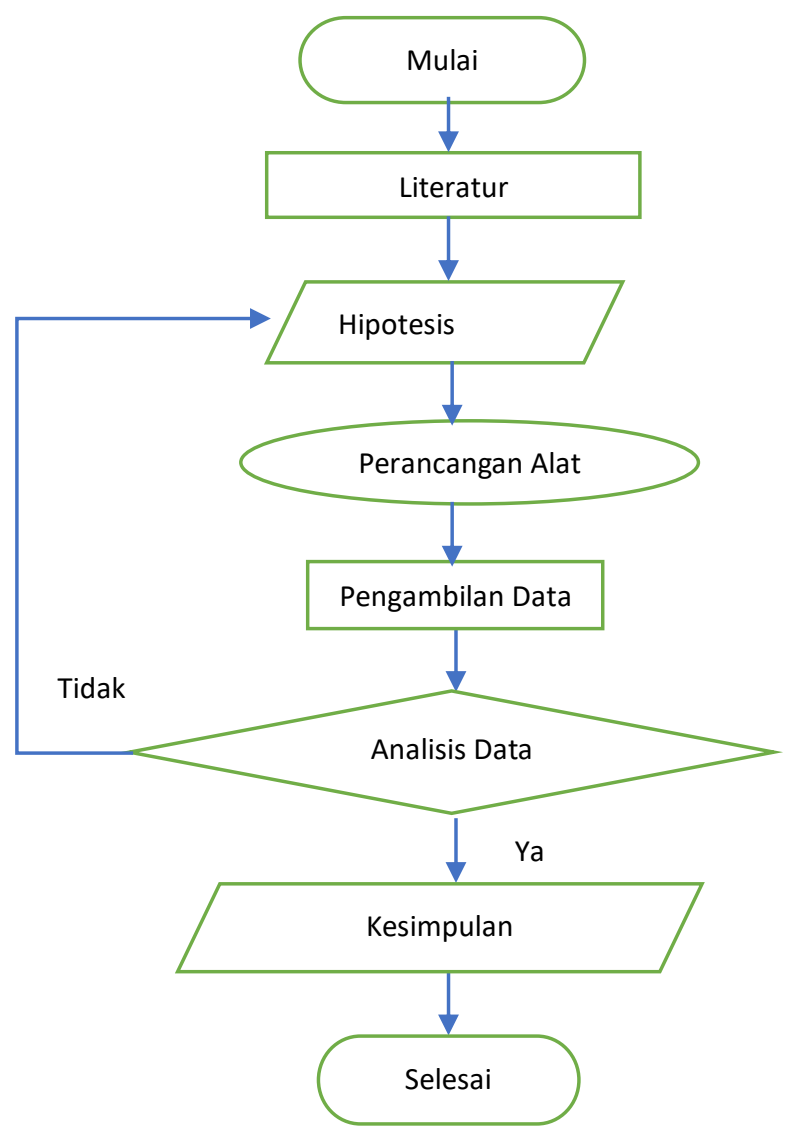

Gambar 1. Flowchart perancangan alat

Sistem hybrid atau Pembangkit Listrik Tenaga Hybrid (PLTH) merupakan salah satu alternatif sistem pembangkit yang tepat diaplikasikan pada daerahdaerah yang sukar dijangkau oleh sistem pembangkit besar seperti jaringan PLN atau PLTD, PLTH ini memanfaatkan renewable Energy sebagai sumber utama (primer) yang dikombinasi dengan solar cell sebagai sumber energi cadangan (sekunder). Pada PLTH, renewable Energy yang digunakan, untuk penelitian menggunakan aliran selokan sawah sebagai sumber energi air, yang dikombinasikan dengan energi matahari sehingga akan menjadi suatu pembangkit yang lebih efisien, efektif dan handal.

\section{Generator DC}

Generator merupakan salah satu mesin listrik yang bekerja berdasarkan energi gerak/mekanik yang kemudian merubahnya menjadi energi listrik. Pada generator DC arah arus saat tegangan negatif dibalik dengan mekanisme cincin-belah, sehingga siklusnya berubah menjadi: positif - nol - positif - nol (tegangan DC).[1].Tegangan induksi generator dapat diketahui dengan persamaan:

Erms $=4,44 x N x f x \emptyset \max X \frac{N_{s}}{N_{p h}}$

dimana:

Erms : Tegangan efektif induksi generator $(\mathrm{V})$

$N \quad$ : jumlah lilitan

f : frekuensi $(\mathrm{Hz})$

Ømax : fluks maksimum (Wb)

Ns : jumlah kumparan

Nph : jumlah fasa

Generator dc yang digunakan didalam perancangan adalah generator kincir air dc magnet permanen, seperti gambar 2 .

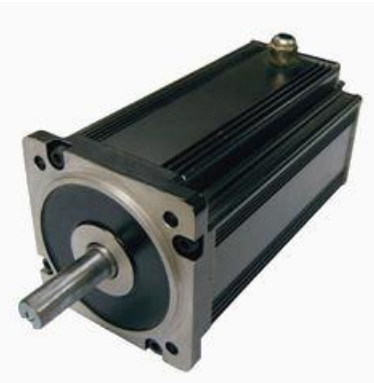

Gambar 2. Generator kincir dc magnet permanen

Dan memiliki spesifikasi sebagai berikut:

- Generator permanen magnet.

- DC 12V-18V 30W 800 RPM.

- Daya: 30W (Max).

- Dimensi :

- Aplikasi: Kincir air, kincir angin.

\section{Accu/baterai}

Baterai atau accu adalah sebuah sel listrik dimana di dalamnya berlangsung proses elektrokimia yang reversibel (dapat berbalikan) dengan efisiensinya yang tinggi. Sedangkan tegangan accu ditentukan oleh jumlah daripada sel baterai, dimana satu sel baterai biasanya dapat menghasilkan tegangan kira kira 2 sampai 2,1 volt. Tegangan listrik yang terbentuk sama dengan jumlah tegangan listrik tiap-tiap sel. Jika baterai mempunyai enam sel, maka tegangan baterai standar tersebut adalah 
12 volt sampai 12,6 volt. seperti diperlihatkan gambar 3 . Accu 12 V DC.[2].

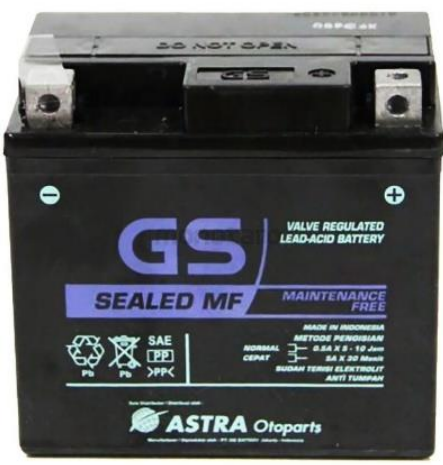

Gambar 3. Accu motor 12V

\section{Dc-dc Converter}

Tegangan searah (DC) pada system tenaga listrik saat ini sangat dibutuhkan. Konverter DC-DC merupakan salah satu jenis rangkaian elektronika daya yang berfungsi untuk mengkonversi tegangan masukan searah konstan menjadi tegangan keluaran searah yang dapat divariasikan berdasarkan perubahan duty cycle rangkaian kontrolnya. Sumber tegangan dc dari konverter DC-DC dapat diperoleh dari baterai, atau dengan menyearahkan sumber tegangan ac yang kemudian dihaluskan dengan filter kapasitor untuk mengurangi riak (ripple).Dc-dc converter merupakan rangkaian elektronika power untuk mengubah suatu masukan tegangan dc menjadi tegangan dc keluaran dengan nilai yang lebih besar atau kecil dari tegangan masukan.[3] Pada perancangan ini, rangkaian $d c-d c$ converter yang akan dibahas merupakan switched-mode $d c-d c$ converter, atau biasa disebut dengan switching power supply. Tegangan dc masukan dari proses $d c-d c$ converter tersebut adalah berasal dari sumber tegangan dc yang biasanya memiliki tegangan masukan yang tetap. Pada dasarnya, tegangan keluaran dc yang ingin dicapai adalah dengan cara pengaturan lamanya waktu perhubungan antara sisi keluaran dan sisi masukan pada rangkaian yangsama. Seperti diperlihatkan pada gambar 4.

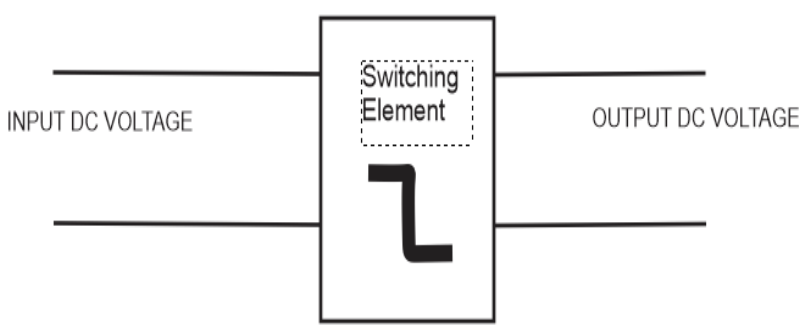

Gambar 4. Dc-dc converter.

Dasar dari switching power supply terdiri dari tiga topologi yaitu buck (step-down), boost (step-up) dan buckboost (step-up/down). Ketiga rangkaian dasar switching power supply ini merupakan nonisolated $d c-d c$ converter di mana masukan dan keluaran dengan grounding yang sama. Pada dasarnya ada dua cara untuk meregulasi tegangan pada switching power supply, yaitu dengan Pulse Width Modulation (PWM) dan Pulse Frequency Modulation (PFM).

\section{Pulse Width Modulation (PWM)}

Merupakan suatu metode pengaturan tegangan dengan mengubah atau mengatur periode ON (Ton) pada tegangan berfrekuensi dengan periode frekuensi yang tetap atau sama. Siklus kerja ini didapatkan dari perbandingan antara lamanya tegangan pada nilai maksimum (Ton) dengan lamanya tegangan pada nilai minimum atau nol (Toff) dan biasa disebut duty cycle (D). Untuk menentukan besarnya duty cycle digunakan persamaan 2 .

duty $\operatorname{cycle}(D)=\frac{\text { Ton }}{\text { Ton+Toff }}=\frac{\text { Ton }}{T}=$ Ton. $F$

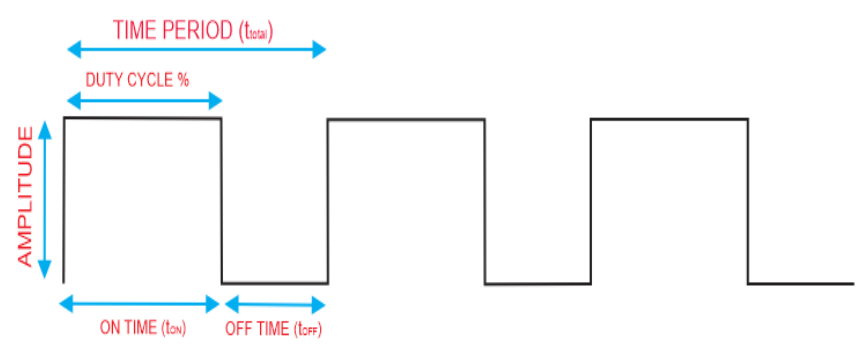

Gambar 5. Pulse Width Modulation (PWM)

\section{Pulse Frequency Modulation (PFM)}

Merupakan suatu metode pengaturan tegangan dengan menjaga Ton tetap konstan dan periode switching ( $\mathrm{T}$ ) dibuat variable terlihat seperti pada Gambar 6. Kelemahan menggunakan metode ini salah satunya adalah sulitnya untuk mendesain LC filter yang tepat.[4].

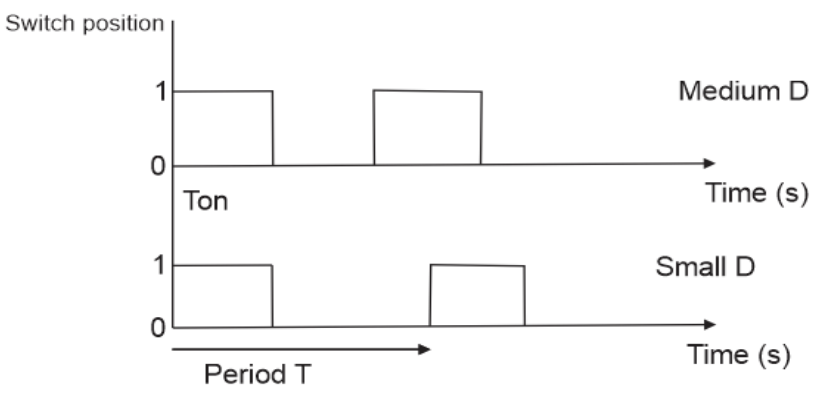

Gambar 6. Pulse Frequency Modulation (PFM)

\section{Boost Converter}

Boost-converter adalah konverter penaik tegangan DC ke level yang lebih tinggi.Ia merupakan bentuk power-supply yang diperlukan ketika tegangan yang dibutuhkan oleh suatu perangkat atau rangkaian elektronik lebih tinggi dari tegangan suplai yang 
tersedia. Sebagaimana buck-converter, boost-converter juga menerapkan sistem SMPS, maka ia adalah bagian dari jenis power-supply SMPS juga.

Boost converter (step-up converter) adalah konverter daya DC-to-DC yang meningkatkan tegangan (saat mengundurkan arus) dari input (pasokan) ke output (beban). Ini adalah kelas catu daya sakelar-mode (SMPS) yang mengandung setidaknya dua semikonduktor (dioda dan transistor) dan setidaknya satu elemen penyimpanan energi: kapasitor, induktor, atau keduanya dalam kombinasi. Untuk mengurangi riak tegangan, filter yang terbuat dari kapasitor (kadangkadang dikombinasikan dengan induktor) biasanya ditambahkan ke output konverter (filter sisi beban) dan input (filter sisi pasokan).[5][6].

Dalam hal ini akan dibahasprinsip kerjaboost converter DC ke DC. Rangkaian dasar boost converter ini hanya menggunakan satu dioda, induktor dan kapasitor. Switch akan menjadi transistor MOSFET dan untuk membuat sinyal PWM akan menggunakan IC LM 2577. Pada rangkaian boost converter pada gambar dibawah berikut dapat dilihat sakelar, induktor, dan kapasitor dan tentu beban ke output. [7][8].

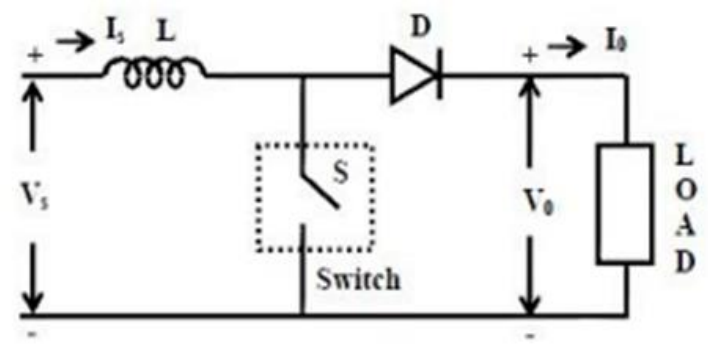

Gambar 7. Rangkaian dasar boost converter

Untuk mendapatkan bahwa output tergantung pada siklus tugas yang tidak proporsional. Jadi semakin besar duty cycle, semakin tinggi outputnya. Siklus tugas PWM dapat memiliki nilai antara 0 dan 1. Jadi, satusatunya output yang mungkin akan sama atau lebih tinggi dari input. Itu sebabnya konfigurasi ini disebut step up converter.Dengan komponen Boost converter sirkuit LM2577-ADJ, memiliki rangkaian umpan balik yang tetap sama dalam beban yang berbeda. [9][10].
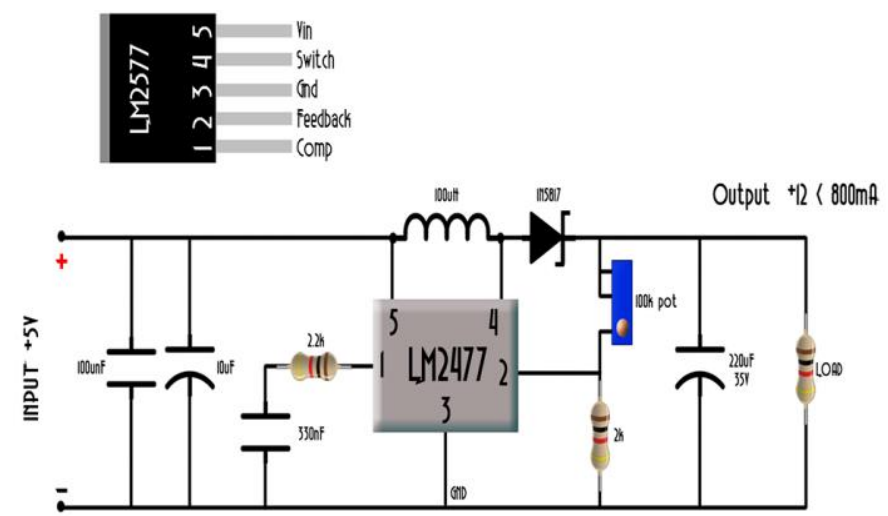

Gambar 8. Rangkaian boost converter sirkuit LM2577

Input bisa hingga 12 volt. Jangan berikan tegangan yang lebih tinggi yang dapat membakar komponen LM2577-ADJ. Dalam hal ini tidak memerlukan saklar eksternal karena LM2577-ADJ sudah memilikinya di dalamnya. Dengan pin umpan balik yang terhubung ke pembagi tegangan output, LM2577-ADJ akan mengubah lebar pulsa tergantung dari output agar tetap konstan. Dalam hal ini gunakan diode Schottky Barrier Rectifier karena memiliki tegangan maju rendah. Dioda ini akan menghidupkan arus saat sakelar terbuka.

Untuk menentukan tegangan keluaran dari boost converter dengan menggunakan persamaan 3 dan 4 .

$$
\begin{aligned}
& V_{\text {out }} V_{\text {in }}\left(1+\frac{t_{\text {on }}}{t_{\text {off }}}\right) \\
& V_{\text {out }} \frac{V_{\text {in }}}{1-D}
\end{aligned}
$$

Pengujian tegangan pada Boost converter yang dilakuakan penulis menggunakan komponen utama IC LM2577 dengan osilator $52 \mathrm{~Hz}$ sebagai frekuensi pensaklaran. Boost converter, bertujuan untuk mendapatkan output de terkontrol dari input dc yang tidak diatur dengan menyesuaikan duty cycle.Boost converter terhubung dengan generator dc dan beban Accu 12V. Siklus konverter yang didapat sesuai dengan persamaan (5).

duty cycle $D=1-\frac{V_{\text {in }}}{V_{\text {out }}}$

\section{Perancangan Alat}

Pada Ssistem Pengujian tegangan boost converter pada pembangkit listrik tenaga air (PLTH) picohydro,dibutuhkan beberapa sistem rangkaian diantaranya generator $\mathrm{dc}$ magnet permanen, accu, inverter dan beban. Serta rangkaian PLTH dan rangkaian boost converter.Berikut adalah gambar tata letak komponen dan layout atau jalur pengawatan yang dibuat menggunakan eagle:

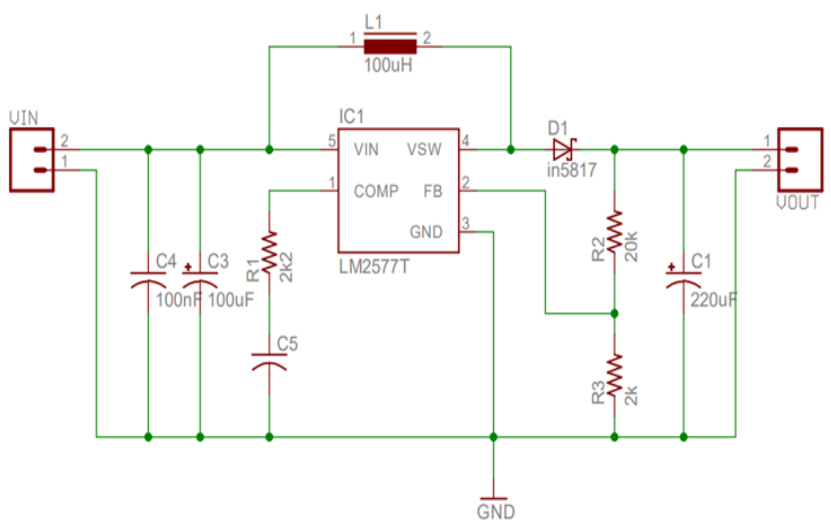

Gambar 9. Rangkaian boost converterpada eagle. 


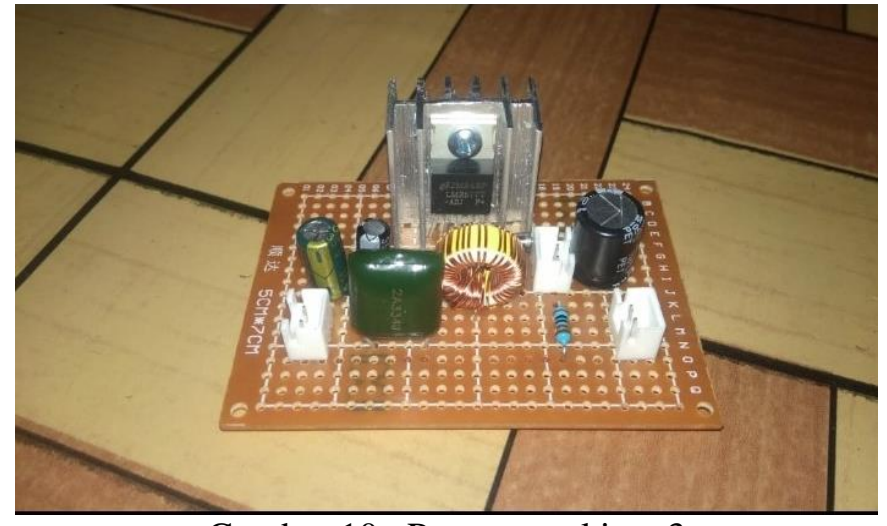

Gambar 10. Proses perakitan 3

\section{HASIL DAN PEMBAHASAN}

Hasil Pengujian tegangan pada boost converterdilakukan setelah semua sistem sudah terhubung, pengujian memiliki tujuan yaitu: Mengetahui referensi atau mencari nilai batas yang harus diberikan pada boost converter.Mengetahui kesalahan-kesalahan atau kekurangan yang ada pada sistem dan diharapkan segera di perbaiki.Mengetahui apakah rangkaian yang dibuat dapat menampilkan nilai output sesuai yang diharapkan. Adapun pengujian peralatan seperti diperlihatkan pada gambar11. Pembangkit Listrik Tenaga Hybrid (PLTH) pico hydro
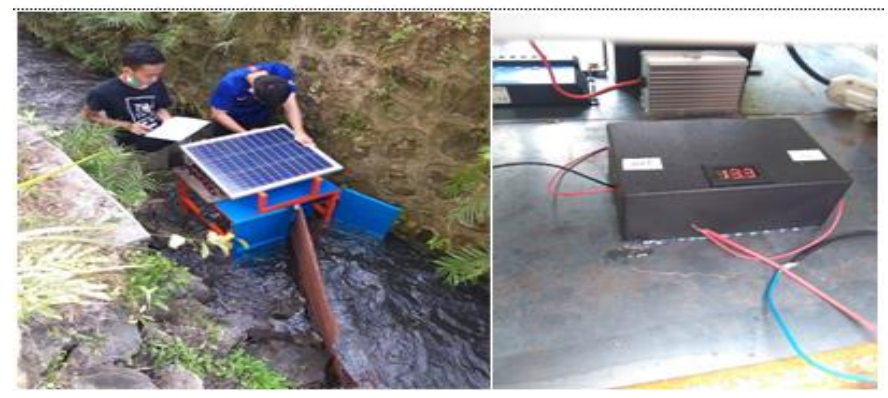

Gambar 11. Pembangkit Listrik Tenaga Hybrid (PLTH) pico hydro

Boost converter digunakan untuk mengubah tegangan DC (V) menjadi keluaran tegangan DC yang lebih besar. Didalam rangkaian ini sebagai saklar pengalihan digunakan komponen IC LM2577 dimana sinyal PWM sebagai pengendalinya. Jika sakelar ON induktor mendapatkan daya dari generator $d c$. Selain itu dioda sebagai reverse bias melepaskan output dari generator PV dan tujuan dipasangnya kapasitor untuk menyimpan arus yang dihasilkan ke beban. Meskipun demikian jika sakelar OFF maka induktor dalam keadaan discharge dan dioda yang terhubung pada output generator PV dalam keadaan forward bias. Tegangan PV dan tegangan pada induktor (dalam keadaan discharge) berkontribusi bersama dalam nilai tegangan output yang dihasilkan. Oleh karena itu tegangan keluaran lebih besar dari pada tegangan masukan yang diberikan.

\section{Pengujian dan analisisdata}

Dari hasil pengukuran di lapangan penelitian yang sudah dilakukan, kemudian dilanjutkan dengan pengujian sekaligus pengambilan data rangkaian boost converter pada Pembangkit Listrik Tenaga Hybrid (PLTH) pico hydro. Ditunjukkan pada table 1.

Tabel 1. Data hasil pengujian

\begin{tabular}{llccccc}
\hline No & $\begin{array}{c}\text { Ketinggian Air } \\
\text { pada Kincir }(\mathrm{m})\end{array}$ & $\begin{array}{c}\text { Putaran Kincir } \\
(\mathrm{rpm})\end{array}$ & $\begin{array}{c}\text { Putaran Generator } \\
(\mathrm{rpm})\end{array}$ & $\begin{array}{c}\text { Tegangan } \\
\text { Generator (volt) }\end{array}$ & $\begin{array}{c}\text { Tegangan } \\
\text { Boost converter (volt) }\end{array}$ & $\begin{array}{c}\text { Arus } \\
\text { ampere }\end{array}$ \\
\hline 1 & $10 \mathrm{~cm}$ & $23 \mathrm{rpm}$ & $362 \mathrm{rpm}$ & $8.7 \mathrm{~V}$ & $12,4 \mathrm{~V}$ & $0.09 \mathrm{~A}$ \\
2 & $20 \mathrm{~cm}$ & $29 \mathrm{rpm}$ & $464 \mathrm{rpm}$ & $8.8 \mathrm{~V}$ & $12,4 \mathrm{~V}$ & $0.09 \mathrm{~A}$ \\
3 & $30 \mathrm{~cm}$ & $43 \mathrm{rpm}$ & $685 \mathrm{rpm}$ & $11.37 \mathrm{~V}$ & $13,4 \mathrm{~V}$ & $0.09 \mathrm{~A}$ \\
\hline
\end{tabular}

Dari gambar 12. Grafik pengujian tegangan pada boos conventer dan generator DC dapat disimpulkan bahwa tiga perbedaan pengujian ketinggian air $(\mathrm{H})$, tidak menunjukan perbedaan yang signifikan pada hasil maka dapat disimpulkan pengujian single kincir ini bekerja dengan baik.

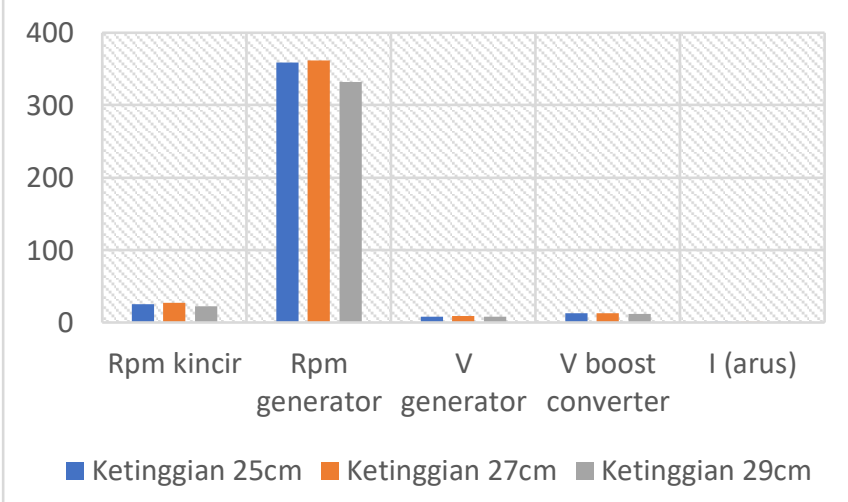

Gambar 12. Grafik Pengujian tegangan pada boos Conventer dan generator DC 


\section{Analisis Perhitungan Daya (Watt)}

- Ketinggian 0,25 m, Tegangan $(\mathrm{V})=$ 13 volt, Arus $(\mathrm{I})=0,86$ ampere $\mathrm{P}=\mathrm{V} \times \mathrm{I}=13 \times 0,86=11,18$ watt

- Ketinggian 0,27 $\mathrm{m}$, Tegangan $(\mathrm{V})=$ 13 volt, Arus $(\mathrm{I})=0,87$ ampere $\mathrm{P}=\mathrm{V} \times \mathrm{I}=13 \times 0,87=11,31$ watt

- Ketinggian 0,29 m, Tegangan $(\mathrm{V})=$ 12 volt, Arus $(\mathrm{I})=0,81$ ampere $\mathrm{P}=\mathrm{V} \times \mathrm{I}=12 \times 0,81=9,72$ watt

\section{Analisis Lama Pengisian Baterai}

Daya Baterai (Wh)

$\mathrm{V}=12 \mathrm{~V}, \mathrm{~A}=5 \mathrm{Ah}, \mathrm{Wh}=\mathrm{V} \times \mathrm{A}=12 \times 5=60 \mathrm{Wh}$

- Ketinggian $0,25 \mathrm{~m}$

Daya Generator (Wh) menggunakan boost converter

$\mathrm{V}=13 \mathrm{~V}, \mathrm{~A}=0,86 \mathrm{~A}$

$\mathrm{Wh}=\mathrm{V} \times \mathrm{A}=13 \times 0,86=11,18 \mathrm{Wh}$

Lama pengisian $=\frac{\text { Daya Baterai }}{\text { DayaGenerator }}$

$$
=\frac{60}{11,18}
$$

$$
=5,3 \mathrm{jam}
$$

- Ketinggian 0,27 m

Daya Generator (Wh) menggunakan boost converter $\mathrm{V}=13 \mathrm{~V}, \mathrm{~A}=0,87 \mathrm{~A}$

$\mathrm{Wh}=\mathrm{V} \times \mathrm{A}=13 \times 0,87=11,31 \mathrm{Wh}$

$$
\begin{aligned}
\text { Lama pengisian } & =\frac{\text { Daya Baterai }}{\text { Daya Generator }} \\
& =\frac{60}{11,31} \\
& =5,3 \mathrm{jam}
\end{aligned}
$$

- Ketinggian 0,29 m

Daya Generator (Wh) menggunakan boost converter $\mathrm{V}=12 \mathrm{~V}, \mathrm{~A}=0,81 \mathrm{~A}$

$\mathrm{Wh}=\mathrm{V} \times \mathrm{A}=12 \times 0,81=9,72 \mathrm{Wh}$

$$
\begin{aligned}
\text { Lama pengisian } & =\frac{\text { Daya Baterai }}{\text { Daya Generator }} \\
& =\frac{60}{9,72} \\
& =6,1 \mathrm{jam}
\end{aligned}
$$

Tabel 2. Pengambilan data hasil pengukuran di lapangan Pengukuran Ketinggian level air $(30 \mathrm{~cm})$

\begin{tabular}{ccccccccc}
\hline No & $\begin{array}{c}\text { Kec.Debit } \\
\mathrm{m}^{2} / \mathrm{s}\end{array}$ & $\begin{array}{c}\text { Putaran } \\
\text { Kincir } \\
\text { (rpm) }\end{array}$ & $\begin{array}{c}\text { Putaran } \\
\text { Generator } \\
\text { (rpm) }\end{array}$ & $\begin{array}{c}\text { Tegangan } \\
\text { Generator } \\
\text { (Volt) }\end{array}$ & $\begin{array}{c}\text { Arus } \\
\text { Generator } \\
\text { (A) }\end{array}$ & $\begin{array}{c}\text { Tegangan Boost } \\
\text { Converter (Volt) }\end{array}$ & $\begin{array}{c}\text { Beban } \\
\text { (Watt) }\end{array}$ & $\begin{array}{c}\text { Arus Beban } \\
\text { (A) }\end{array}$ \\
\hline 1 & 0,571 & 38 & 608 & 8,7 & 0,78 & 11,4 & 45 & 0,28 \\
2 & 0,571 & 38 & 610 & 8,7 & 0,78 & 11,4 & 40 & 0,20 \\
3 & 0,571 & 38 & 611 & 8,8 & 0,79 & 11,5 & 35 & 0,22 \\
4 & 0,571 & 38 & 612 & 8,9 & 0,81 & 11,6 & 30 & 0,21 \\
5 & 0,571 & 38 & 614 & 8,9 & 0,82 & 12,4 & 25 & 0,11 \\
6 & 0,571 & 38 & 614 & 9,4 & 0,84 & 12,4 & 20 & 0,18 \\
7 & 0,571 & 39 & 624 & 10,8 & 0,86 & 12,4 & 15 & 0,09 \\
8 & 0,571 & 39 & 626 & 10,9 & 0,87 & 12,8 & 10 & 0,19 \\
9 & 0,571 & 43 & 685 & 11,37 & 0,89 & 13,4 & 5 & 0,09 \\
10 & 0,571 & 43 & 685 & 11,37 & 0,89 & 13,4 & 0 & 0 \\
\hline
\end{tabular}

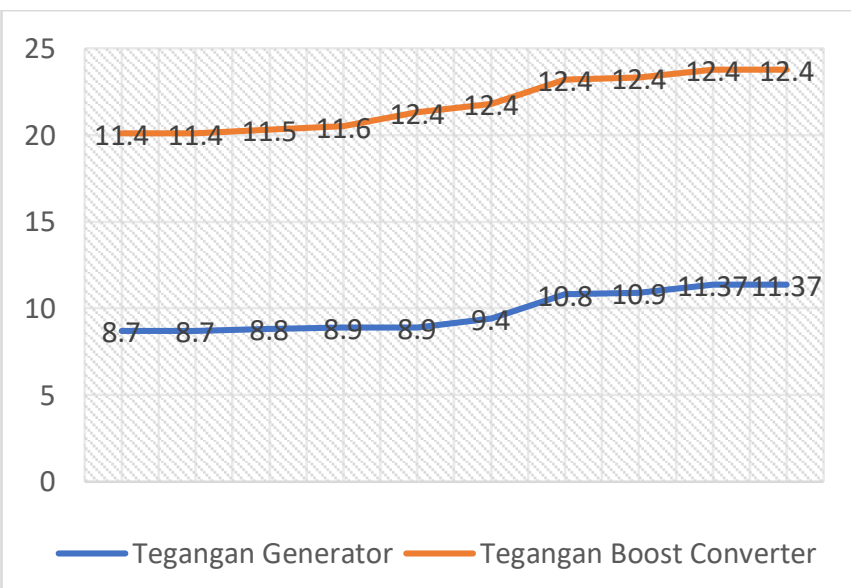

Gambar 13. Grafik Perbandingan Tegangan Generator dengan Boost Konverter

\section{SIMPULAN}

Berdasarkan hasil analisis dari pengujian tegangan dan pengambilan data dilapangan dapat disimpulkan tentang pengujian boost converter pada PLTH sebagai berikut.

1. Hasil pengujian tegangan boost converter, pada Pembangkit Listrik Tenaga Hybrid Pico Hydro dapat menghasilkan tegangan sebesar 13 volt dari output Generator DC sebesr 8,39 volt.

2. Tegangan keluaran yang dihasilkan oleh boost convertersebesar 12,4-13,4 volt, dapat stabil walaupun tegangan keluaran dari generator berubahubah.

3. Dengan penambahan alat boost converter pada PLTH pico hydro, dapat membantu pengisian baterai/accu untuk mengisi tegangan yang dibutuhkan baterai yaitu 12 volt, dari boos convevter 13,4 volt lama waktu pengisian accu 5,3 jam.

4. Boost converter dapat sedikit membantu kinerja tegangan generator yang digunakan, karena pada sungai (tempat pengujian) arus debit air menghasilkan 362rpm pada ketinggian $10 \mathrm{~cm}$ dengan 
output generator 8,7 volt, $464 \mathrm{rpm}$ pada ketinggian $20 \mathrm{~cm}$ dengan output 8,8 volt dan $685 \mathrm{rpm}$ pada ketinggian $30 \mathrm{~cm}$ dengan output generator 11,37 volt naik menjadi 13,4 volt pada boost converter.

\section{DAFTAR PUSTAKA}

[1]. J. Dudrik, M. Pastor, M. Lacko, R. Zatkovic, "ZeroVoltage and Zero-Current Switching PWM DC-DC Converter Using Controlled Secondary Rectifier with One Active Switch and Nondissipative TurnOff Snubber", IEEE Transactions on Power Electronics, Vol. 33, No. 7, pp. 6012-6023, 2018.

[2]. Saodah S, Sri Utami S., 2018.,"Perancangan Inverter Menggunakan Buck Bost Converter Dua Level" Prosiding Seminar Nasional Vokasi Indonesia, Vol 1, e.ISSN 2654-6493, pp.55-59.

[3]. Fahmi Umarella, "Analisa Induktor Toroid Binokuler Pada Rangkaian Boost Converter", Laporan Tugas Akhir Jurusan Teknik Elektro Universitas Indonesia Depok, Hal.1, 2014

[4]. Hendi Matalata,Leily W Johar, 2018, Analisa Buck Converter Dan Boost Converter Pada Perubahan Duty Cycle Pwm Dengan Membandingkan Frekuensi Pwm 1,7 Khz Dan 3,3Khz, Jurnal Ilmiah Universitas Batanghari Jambi Vol.18, No.1

[5]. Venny Y., 2018" Perancangan Bosst Konverter Sebagai Penguat Umpan Balik Charnger Control Baterai Pada Panel Surya" Jurrnal Civronlit Universitas Batanghari Vol.3 N0.2.pp.98-103, Oktober 2018.

[6]. Venkateswra Rao, Ch., S.S.Tulasiram, B.Brahmaiah, 2015, "Digital ControlLED High Power Synchronous Boost Converter Based Mppt Charge Controller For Spv System", International Journal of Innovations in Engineering and Technology (IJIET), Vol. 5 No. 1, pp. 104-110, April 2015.

[7]. T.NageswaraRao., V.C. Veera Reddy, (2012)“A NovelEfficient Soft Switched Two Ports Dc-Dc BoostConverter With Open Loop And Closed Loop Control".Indian Journal of Computer Science andEngineering,Volume: 3 Issue: 3 PP: 394-400

[8]. Vikas Shrivastava, Seema Deshmukh "Analysis andStudy Between Two Soft Swiching Techniques Used inBoost Converter Implementattion" InternatioalConference onElectrical, Electronics, Communication,Mechanical, Coputing (EECCME)2018, IEEE Madras.

[9]. M.Z. Hossain, N.A. Rahim, J. Selvaraj, "Recent Progress and Development on Power DC-DC Converter Topology, Control, Design and Applications: A Review", Renewable and Sustainable Energy Reviews, Vol. 81, pp. 205-230, 2018.

[10].K.I. Wu, B.T. Hwang, C.C.P. Chen, "Synchronous Double- Pumping Technique for Integrated Current-
Mode PWM DC-DC Converters Demand on FastTransient Response", IEEE Transactions on Power Electronics, Vol. 32, No. 1, pp. 849-865, 2017.

[11].C. Liu, J. Kan, Y. Zhi, W. Li, J. Sun, G. Cai, J. Wang, Reliable transformerless battery energy storage systems based on cascade dual-boost/buck converters, IET Power Electronics, Vol. 8, Iss. 9, pp. 1681-1689, 2015.

[12] Syafriyudin, 2018, Early Analysis Of Jumping Water Effect On Breastshot Waterwheel For Microhydro Power Plant, Journal of Physics: Conf. Series 953; 012039. 